\title{
Exploring the Development of Islamic Banking in Nigeria using an Actor-Network Theory Perspective
}

\section{Hadiza Sa'id}

\begin{abstract}
Purpose - The purpose of this paper is to investigate the evolution of Islamic banking in Nigeria.
\end{abstract}

Design/methodology/approach - The paper adopts a qualitative approach using 25 semi-structured interviews together with documentary analysis in order to analyse how Islamic banking has evolved in Nigeria.

Findings - The paper demonstrates that the evolution of Islamic banking in Nigeria arose from a relationship between various human and non-human actors. The development was shaped by the Nigerian socio-economic environment, particularly the wealthy Muslim segment and the poor performance of the economy.

Originality/value - The paper differs from previous studies on the development of Islamic banking in two ways. First, it provides a contextual account of the various factors that have influenced the development of Islamic banking in Nigeria, a sub-Saharan Africa country for which research on Islamic banking is sparse. Second, the paper is unique in analysing how Islamic banking emerged as a process of actor-network formation.

Keywords - Islamic banking, Nigeria, actor-network theory, Islamic finance

Paper type - Research paper 


\section{Introduction}

In recent decades, Islamic finance has become a trend in Islamic countries, as well as in some non-Muslim countries. This trend began to grow following the independence of Islamic countries from the colonial powers and the quest to have sharia-compliant financial products and institutions (Haniffa and Hudaib, 2010; Warde, 2010). According to the Islamic Financial Services Board, the total assets of Islamic financial services stood at USD1.88 trillion as at 2015 (IFSB, 2016). However, the adoption of Islamic finance is not a straightforward matter.

Various scholars have investigated the development of Islamic finance in different countries. Studies have been conducted in countries such as Pakistan (Khan and Bhatti, 2006; Khan, 2008; Rammal and Parker, 2013; Khan and Mirakhor, 1990), Iran (Khan and Mirakhor, 1990), Malaysia (Laldin, 2008; Al Nasser and Muhammed, 2013) Bangladesh (Sarker, 1998), Tunisia (Kaabachi and Obeid, 2016), Jordan (Maali and Napier, 2010), Egypt (Mouawad, 2009) and Algeria (Benamraoui, 2008). These studies highlighted the influence of the social, economic and political environment on the development of Islamic finance. Some studies revealed how politics can impede the development of Islamic finance. For instance, in a study of Islamic finance development in Egypt, Mouawad (2009) highlighted how the Egyptian government used it powers to hinder the development of Islamic finance in the country. Similar findings were reported by Khan and Bhatti (2006), Khan (2008), Maali and Napier (2010) and Young (1983). Other researches, such as Laldin (2008), Khan and Mirakhor (1990) and Al Nasser and Muhammed (2013), have explored how the governments in Malaysia and Iran supported the development of Islamic banking and finance in the respective countries. Benamraoui (2008) highlighted how economic changes due to the liberalisation policy adopted by the Algerian government have positively influenced the development of Islamic banking.

The above papers also revealed the importance of context in the development of Islamic finance, demonstrating the need to analyse the development of Islamic finance in other countries. Consequently, this paper aims to explore and explain the evolution of Islamic banking in Nigeria. This will add to the body of literature on the development of Islamic finance by analysing how Nigeria's socio-economic and political environment have influenced the development of such financing. This is in line with the recent call for research on Islamic banking in countries such as Nigeria, where Islamic banking studies are sparse (Hassan and Aliyu, 2018). 
Studying Nigeria is important, given that the first Islamic bank was established in the late 1950s in Pakistan (Maali and Napier, 2010) but Nigeria's first fully Islamic bank was not opened until 2012. The country is ranked fifth in the world in terms of the number of Muslim citizens (World Atlas, 2018), with more than 90 million Muslims living in the country, this raises a question as to why Islamic finance is limited in the country, given the popularity of Islamic financial products in recent decades. Furthermore, the case of Nigeria is unique because the country is a secular state but half of the population are Muslim (CIA, 2017). It can be argued that these Muslims were not given a chance to practise their religious obligations like in Middle Eastern and Southeast Asian countries, particularly concerning avoiding riba (interest) in line with their beliefs, as stated in the Holy Qur'an.

O' you who have Faith! Be in awe of Allah, and forgo what remains (due to you) of usury, if you are faithful. Surah Al-Baqarah, Verse 278

Furthermore, Haniffa and Hudaib (2010) in an editorial note show how the intention to establish Islamic finance to help Muslims avoid riba (usury) can be affected by secular goals as a result of political and socio-economic events and the interaction of Islamic finance with conventional finance. The authors call for research on a country basis to explore this dynamic. In exploring the Nigeria's dynamics, this paper draws on actor-network theory (ANT) (Callon, 1986, 1987, 1991; Latour, 1987, 1992) in collecting and interpreting data. Latour suggests that researchers should study science/technology in action, not a readymade science/technology (Latour, 1987). This argument suggests that researchers should focus on the processes rather than merely on outcomes. From the ANT perspective, the development of Islamic finance can be seen as a process of diffusion of ideas-based technology. ANT enables us to study the process of how Islamic banking has evolved in Nigeria.

The concept of ANT has been widely adopted in business and accounting research (Chua, 1995; Makkonen et al., 2012; Robson and Bottausci, 2018). Hence, this paper aims to contribute to literature on the development of Islamic banking by providing a theoretical analysis of how Islamic banking evolved in Nigeria, and in the process explores how the Islamic banking network was formed and is maintained and how Nigerian socio-economic and political factors shaped its development.

The paper is subsequently divided into four parts. The next section discusses the literature on the development of Islamic finance and the concepts of ANT. Section 3 describes the Nigerian 
context and the description of the research method adopted for the study. Section 4 presents the discussion and analysis. The final section concludes the paper and summarises how Islamic banking evolved in Nigeria.

\section{Literature Review and Theory}

Significant attention has been paid to Islamic finance by academics, practitioners and policymakers. The International Monetary Fund (IMF) defines this method of finance as:

[the] provision of financial services in accordance with Shari'ah Islamic law, principles and rules. Shari'ah does not permit receipt and payment of "riba" (interest), "gharar" (excessive uncertainty), "maysir" (gambling), short sales or financing activities that it considers harmful to society. Instead, the parties must share the risks and rewards of a business transaction and the transaction should have a real economic purpose without undue speculation, and not involve any exploitation of either party. (IMF, 2017)

Islamic finance comprises banking, leasing, sukuk (securities), equity markets, investment funds, microfinance and takaful (insurance). However, 95\% of Islamic finance assets are in the form of banking and securities (IMF, 2017).

There have been many publications on the development of Islamic finance institutions (e.g. banks); Islamic financial products; customers' satisfaction with Islamic finance; perceptions of Islamic finance; the efficiency of Islamic banks; and the ethics of Islamic finance are among the topics debated (see, for instance, Naseer et al., 1999; Saaid et al., 2003; Saaid, 2005; Saini et al., 2011; Khan and Bhatti, 2006; Haniffa and Hudaib, 2007; Laldin, 2008, Rammal and Parker, 2013; Lewis, 2011; Al Nasser and Muhammed, 2013; Ringim, 2014; Yunusa and Nordin, 2015; Mbawuni and Nimako, 2017).

Research on the development of Islamic banking has been conducted in various Muslim countries, with studies highlighting several country-specific factors that arise during the development of Islamic banking due to the social, economic and political environment. For instance, Rammal and Parker (2013) examined the events that shaped the Islamic banking sector in Pakistan. The authors reported the complexity of reforming banking to a purely Islamic system, and revealed that there were conflicting demands from different stakeholders. Khan and Bhatti (2006) studied the failure of the Pakistani interest-free movement of the late 1970s to the early 2000s. The authors attributed the lack of success to globalisation pressures and the privatisation of the Pakistani economy. In a similar study, Khan (2008) attributed the 
failure of the interest-free movement to political insincerity, politicians' vested interests, a lack of training and power struggles. However, Benamraoui (2008) reported a different finding in a study of the development of Islamic banking in Algeria: the financial liberalisation in Algeria aided the development of Islamic banking.

Other studies on Islamic banking such as those of Laldin (2008) and Al Nasser and Muhammed (2013), have shown how the governments supported the development of Islamic finance in some countries. Laldin (2008) studied the development of Islamic finance in Malaysia, drawing from published materials including books, statistics, reports, presentations and conference papers, and revealed how the government supported the development of Islamic banking. Al Nasser and Muhammed (2013) reported that Malaysia has a strong infrastructure that has supported the development of Islamic banks. However, other studies have reported tensions between Islamic banking development and the governments. For instance, in a study of the creation of Jordan's first Islamic bank, Maali and Napier (2010) reported significant economic and religious (social) tensions during the creation of the bank. In the same vein, Mouawad (2009) investigated the attitudes and policies of the Egyptian government towards Islamic banks. He reported how the government used its power to slow development of the sector. The Egyptian government was sceptical of the nature of Islamic banking products, the links to Islamic groups and the effects that Islamic banking would have on the economy. Similarly, in Turkey the lack of government support hindered the development of Islamic banking in the 1980s and 1990s (Yanīkkaya and Pabuçcu, 2017). Moreover, Wilson (2013) evaluated the development of Islamic banking in the Gulf Cooperation Council (GCC) States. Wilson reported that Islamic banks received mixed support from the GCC states. The support from Saudi Arabia and Oman governments were limited while Kuwait, Bahrain, the United Arab Emirates and Qatar governments provided significant support to the development of Islamic banking.

Authors such as Imam and Kpodar (2013) and Cham (2018) analysed the determinants of Islamic banking growth using data from various countries. Imam and Kpodar (2013) reported that the development of Islamic banking is linked to countries with higher Muslim population, economic stability and a strong economic relationship with Middle Eastern states. Cham (2018) reported that this development is aided by higher oil prices, steady domestic prices, a more educated population and higher capital resources. 
The above-reviewed studies reported mixed findings, thus warranting country-specific studies. Furthermore, the majority of these studies concentrated on the Middle East and Southeast Asia. There have been limited studies on the development of Islamic banking in sub-Saharan Africa in general and Nigeria in particular. Of the few studies identified, most were on topics such as the challenges and efficiency of Islamic banks (Saaid et al., 2003; Saaid, 2005; Yunusa and Nordin, 2015), awareness of Islamic banking (Saini et al., 2011), the determinants of adoption of Islamic banking (Mbawuni and Nimako, 2017), the Sudanese Islamic banking system (Mohsin, 2005), and perceptions, awareness and usage of Islamic banking products (Ringim, 2014; Saini et al., 2011). Few studies have investigated the development of Islamic banking in sub-Saharan Africa (Hassan and Isa, 2018), despite the fact that the region is home to around 250 million Muslims (Economist, 2017). In addition, most sub-Saharan African countries have recorded significant growth in their financial sectors in recent decades, but Islamic finance growth has been very small in the region (Gelbard et al., 2014). In a study of the Islamic finance market in Africa, Faye et al (2013) reported that there were limited numbers of providers of Islamic finance in Africa in general but that sub-Saharan Africa suffers more. Faye et al reported further that among the 21 countries they studied, Islamic banks represent less than $10 \%$ of the commercial banks operating in the countries. This finding is contrary to that reported by Khan and Bhatti (2008) in a study of Islamic finance development globally; they reported that Islamic banking is becoming an alternative to conventional banking.

Furthermore, the total assets of global Islamic finance in 2017 stood at approximately $\$ 1.9$ trillionin; sub-Saharan Africa accounts for only about 2\% of these assets (Economist, 2017). Consequently, this paper argues that by studying the evolution of Islamic banking in a subSaharan African country, a significant contribution can be made to the literature in terms of understanding the factors that support/hinder the development of Islamic banking in the region. Nigeria was picked as the case site due to the significant number of Muslims living in the 
country. In addition, Nigeria has a significantly developed banking industry in comparison to many sub-Saharan African countries; for example, a KPMG Report titled "Financial Services in Africa" ranked Nigerian banking sector third in Africa, having 9 per cent of the top 200 banks in Africa (KPMG, 2013). However, the country's first Islamic bank was established in 2012. Thus, understanding is required as to why Islamic banking was not developed in the 1970s, as in other majority Muslim countries.

To explore and understand the development of Islamic banking in Nigeria, we employ ANT. The theory originates from the field of science and technology and focuses on explaining how actor-networks are formed, are maintained or eventually break down (Callon, 1986, 1987, Latour, 1987, 1992). Latour (1992) argues that scientific innovations are developed through networks as a consequence of the enrolment of human and non-human allies into those networks. Thus, together, these human and non-human allies (actors) contribute to the development of scientific and technological innovations. In his famous work Science in Action (1987), Latour emphasises the importance of bringing both human and non-human actors together in the network:

Fact construction is so much a collective process that an isolated person builds only dreams, claims and feelings, not facts... One of the main problems to solve is to interest someone enough to be read at all; compared to this problem, that of being believed is, so to speak, a minor task. (Latour, 1987, p. 41)

Thus, signifying the production of science and technology involves the enrolment and negotiation of various actors into the network.

The process of developing scientific and technological knowledge discussed above can also be extended to other analyses and can contribute to the understanding of how institutions or practices evolve. ANT treats the social world as a set of related parts with no defined social order; instead, the social world evolves as a result of continuous attempts at ordering through the formation and stabilisation of networks (Stanforth, 2006). Thus, social order is an effect generated by heterogeneous means, and the network is important because this is where both human and non-human actors interact to create social order. 
How actor-networks are built is explained by the process of translation (Callon, 1986, Latour, 1987). Translation has four main stages, namely problematisation, interessement, enrolment and mobilisation (Callon, 1986). Problematisation is the process by which the main actors define the identity of other actors and persuade these other actors to subscribe to their view by showing them that they have the right solutions. Interessement is the actions that the main actors employ to impose and stabilise the identity of the other actors they defined through their problematisation. Enrolment is the creation of aligned networks. This is the successful outcome of problematisation and interessement. Mobilisation refers to the monitoring of actors' various interests to ensure that they remain stable. Successful mobilisation results in actors speaking in the same voice, thus creating a consensus network. However, this consensus network can be contested at any time (Callon, 1986). These four main stages explain the process of translation how ideas and practices come to be formed and accepted in an actor-network.

Using ANT, we study the evolution of Islamic banking as a technology system. We follow the actors involved in the development of the Islamic banking network in Nigeria. Drawing from the four moments of translation (Callon, 1986), we analyse how Islamic banking practice was translated to Nigeria.

\section{Context and Methods}

Nigeria, a former British colony, is the largest economy in Africa and has an estimated population of 190,632,261: about 50\% of the population are Muslim, 40\% are Christian and the remaining $10 \%$ hold indigenous beliefs (CIA, 2017). The country is multi-ethnic, with more than 250 ethnic groups (CIA, 2017). Nigeria gained its independence from Britain on 1 October 1960. The independent Nigeria inherited a Westminster-type of democracy and many other rules and regulations left by the colonial authorities (Okike, 1994). A formal banking system was established in Nigeria during the colonial period, when African Banking Corporation was opened in Lagos in 1891 (Rowan, 1952). Nigeria's early banks were mostly foreign owned, several fully and partly indigenous banks were opened in the 1930s, but most of them collapsed (Beck et al., 2005). During that time, there were no banking regulations. Nigeria's first banking regulation was enacted in 1952 as a result of an inquiry by the colonial administrators into banking practices in Nigeria, leading to the promulgation of the Banking Ordinance, which aims to ensure order in commercial banking practices and the formation of banks (CBN, 2017). The Central Bank of Nigeria (CBN) began operation on 1 July 1959, after the approval of the House of Representatives in 1958; the CBN Act was subsequently amended in the 1990s, with 
the latest amendment in 2007 (CBN, 2017). The CBN is charged with control and administration of Nigeria's monetary and financial sector policies. The first legislation for the establishment of commercial and merchant banks in Nigeria was the Banking Act 1969 (CBN, 2017). However, there was no provision for Islamic finance in this first legislation. The Nigerian banking system has faced various challenges, and its banks have undergone various reforms. See Beck et al. (2005) for a detailed analysis of the Nigerian banking system and its reforms. Islamic finance was recognised in Nigeria's law in 1991, when the Banks and Other Financial Institutions Decree (BOFI) was enacted. The BOFI Decree repealed the 1969 Banking Decree and all its amendments. In the BOFI Decree, non-interest banking (Islamic banking) was recognised. Thus, this study will explore the effect of the legislation on Islamic banking through a qualitative approach.

The study data was collected through a combination of interviews and documentary analysis (Eisenhardt, 1989). A total of 25 semi-structured interviews were conducted with Nigerian Muslims and non-Muslims in 2015, 2016 and 2018 (see Appendix 1). The interviewees comprised 18 men and seven women. The interviewees were selected based on convenience sampling (Hair et al., 2007). Interviews can take the form of face-to-face, voice-to-voice or screen-to-screen (Hussey and Hussey, 1997). Twenty of the interviews were face-to-face while the remaining five were conducted via Skype. Eighteen of the interviews were transcribed while the remaining seven were not, based on the respective interviewee's request. However, notes were taking during all the interviews. In addition, documentary evidence was collected from the CBN's publications, Nigerian newspapers and Jaiz International Bank's website. The data was analysed using continuous data reduction, which is a method of data analysis that discards irrelevant data and continues collecting data relevant to the study (Collis and Hussey, 2009). However, not all data collected that was irrelevant was discarded, as the author reanalysed the data many times; in some cases, some data became relevant. The data was further restructured into various actors and categorised using ANT's four stages of translation (Callon, 1986; Collis and Hussey, 2009).

\section{Analysis and Discussion}

The analysis and discussion are divided into two parts. The first part discusses the evolution of Islamic banking before the 2000s and the second part discusses its development after the 2000s. 


\subsection{The Evolution of Islamic Banking in Nigeria Before the 2000s}

According to ANT, the evolution of Islamic banking can be conceptualised as a network of relationships between various human and non-human actors (Callon, 1986; Latour, 1987). Consequently, the human and non-human actors involved in the development of the Islamic banking network in Nigeria were traced (see figure 1).

[Insert Figure 1 near here]

The actors followed were the CBN, Jaiz International Bank, Nigeria's Muslims, Nigeria's Christians, Nigeria banking legislation and Nigeria's government.

Our findings reveal that the emergence of Islamic finance in Nigeria can be trace back to the $19^{\text {th }}$ century, during the period of Sheikh Usman Dan Fodio's revolution and the subsequent establishment of the Sokoto Caliphate (Mustafa and Idris, 2015). Financial activities similar to modern-day Islamic finance took place during the period (Mustafa and Idris, 2015). The caliphate was obliterated in 1903, following colonial intervention and the subsequent seizure of the territory. Like other Muslim countries, following Nigeria's independence from Britain in 1960, an attempt to establish Islamic banking was made in 1961. A bank called Muslim Bank West Africa Limited was created in Lagos; however, the bank was closed in 1962 by the then Finance Minister (Ajayi, 1999 cited in Orisankoko, 2012).

Islamic banking become a global phenomenon in the 1970s (Haniffa and Hudaib, 2010; Warde, 2010). It grew widely in Islamic countries (Khan and Mirakhor, 1990; Maali and Napier, 2010; Faye et al., 2013). Our study findings revealed that the Islamic banking surge of the 1970s was not accepted in Nigeria at that time. It was in the 1980s when Nigerian Muslim actor group, who were becoming wealthier and wanted to have financing that was in line with their religion, problematised Islamic banking. This is similar to the finding reported by Wilson (2013) that Islamic banking development in GCC states was facilitated from the bottom up. This group of actors began building an Islamic banking network. Interessement devices such as campaigns, sermons, Islamic conferences and publications in the media were adopted to interest other actors in the network they were building. A prominent conference was the 1985 International Conference on Islamic Economics hosted by Usman Danfodio University, Sokoto in collaboration with other university. During the conference, Islamic banking was introduced to the Nigerian public. Many Nigerian Muslims, academics and Muslim religious groups became part of the network. According to one interviewee: 
We were very excited about the notion of having a bank in line with our faith. We started discussing how we can make that happen. This is like a dream come true. Personally, I hate interest, however, I cannot keep my money at home because of arm robbers.

However, for Islamic banking networks to be successful, there must be government legislation that supports them. A bank manager noted this as follows:

Islamic banking could not prosper at that time. The Nigerian banking regulation has no provision for Islamic financing or banking. For Islamic banking to evolve, Nigeria's banking regulations have to be changed.

Thus, highlighting need for government to be enrol into the network. Nigeria is the biggest economy in Africa and a major oil producer, with the largest oil reserve in Africa (World Bank, 2017). The country has been recording poor growth in the real economy. According to the World Bank, around $53.5 \%$ of Nigerians lived on under $\$ 1.90$ a day. The Nigerian government began to see Islamic financing as a way of reducing poverty. Consequently, our finding revealed that in 1991, the government recognised Islamic financing when it enacted the BOFI Decree. The Decree was passed as a result of an increase in banks and other financial institutions, which was instigated due to the adoption of the Structural Adjustment Programme's liberalisation and regulation measures to improve the economy (CBN, 2017). The Decree was intended to strengthen the financial sector. It permits the establishment of profit- and loss-sharing banks, thus paving the way for the creation of Islamic banks and other methods of Islamic financing. This strengthened the Islamic banking network, as it made Islamic banking options possible in Nigeria. This is similar to Benamraoui's (2008) finding that the liberalisation policy aided the development of Islamic banking in Algeria. The BOFI Decree defines a profit- and loss-sharing bank as a "bank which transacts investment or commercial banking business and maintains profit and loss sharing accounts" (Law Nigeria, 1991). One interviewee stated this as follows:

The change in the banking legislature gave us hope that we can actually have an Islamic bank. We began planning how we can raise capital and the necessary documentation to float an Islamic bank.

Moreover, we found that following the change in the banking regulation, Nigerian banks and other financial institutions were enrolled and mobilised into the actor-network. Habib Bank [1] was the first bank to offer Islamic banking. The bank applied for a licence, which the CBN 
granted in 1992; in 1996, Habib Bank began operating a non-interest banking service. Several Muslims opened accounts with the bank. According one interviewee:

The non-interest banking was an answer to my prayers from god. I hate seeing interest being credited in my account. Even though I normally give the interest to the needy. However, I feel like I was not doing the right thing.

However, not much success was recorded by Habib Bank, which some interviewees put down to the lack of non-human actors' enrolment into the network in terms of the government having a detailed regulatory and supervision framework for non-interest banking as that time.

\subsection{Development of Islamic Banking in Nigeria After the 2000s}

Our findings reveal that the Islamic banking network become stronger when an attempt was made to open a fully Islamic bank in 2003. Jaiz International Bank Plc was set up by several educated and wealthy Muslims with the aim of floating a fully fledged Islamic bank. To meet the CBN's required capital base of NGN2 billion, the bank went to the Nigerian Stock Exchange (NSE) and sourced NGN2.5 billion through an initial public offering. According to one interviewee:

The shares were subscribed very quickly. Many Muslims bought the shares to hasten the floatation of the bank. I think the surge may have been a result of religious sentiment. You know in Nigeria we are very sentimental about religion. Many people bought the shares, I believe, because they heard they had something to do with Islam.

Following the initial public offering, Jaiz International Bank applied to the CBN for a banking licence in 2004. The licence was granted in principle in 2005. However, the network suffered a setback because the $\mathrm{CBN}$ began reforming the banking sector, giving a directive to all Nigerian banks to either increase their capital base to NGN25 billion by 31 December 2005, or merge with other banks to meet the new capital requirement. According to the CBN Governor, Professor Charles Chukwuma Soludo:

The goal of the reforms is to help you [Nigerian banks] become stronger players, and in a manner that will ensure longevity and hence higher returns to your shareholders over time and greater impacts on the Nigerian economy. We strongly believe that the ultimate beneficiaries of this policy shift would be the Nigerian economy---- the ordinary men and women who can put their deposits in the banks and have a restful sleep; the entrepreneurial Nigerians who can now have stronger financial system to finance their businesses; and Nigerian economy which will benefit from internationally connected and competitive banks that would also mobilize international capital for Nigerian development. This measure is about ... positioning Nigeria and Nigerians to become competitive players in the 21 st century. (Soludo, 2006, p 1) 
Thus, the approval of the only fully Islamic bank came with the condition of meeting the new capital requirement. There were no banks to come to Jaiz International Bank's aid at that time. However, Jaiz bank got some support from the Zamfara State government. Zamfara state was the first state in Nigeria to introduce sharia law in 1999. In line with sharia law, the Zamfara state government created Halal Islamic Bank. Halal Islamic Bank was merged with Jaiz International Bank in order to raise the required capital and create a stronger bank; thus, the Zamfara state government joined the network. However, the problem of raising NGN25 billion in capital continued.

Our analysis revealed that during the post-2000 period, the Nigerian government became the focal actor in the development of the Islamic finance network. The government made various efforts to strengthen the model by linking translations, alongside generating other translations and bringing in more actors (Callon, 1991). For instance, in 2004, a delegation led by the CBN's Deputy Governor was sent to Malaysia to study how the country's Islamic banking operated. The government's commitment to the development of the Islamic finance network was strengthened when Nigeria joined the Islamic Development Bank (IDB) in 2005; thus, the IDB become an actor. Further actors, such as Enhancing Financial Innovation and Access (EFInA, 2009) [2], joined the network, setting up the non-interest Finance Working Group in 2009 (EFInA, 2009). The EFInA initiative may be ascribed to the global recognition of financial inclusion as the means for economic development, and Islamic finance was recognised as a method that would help to increase financial inclusion (Lagarde, 2015). A further international actor, the International Finance Corporation (IFC), was enrolled into the network due to its interest in improving financial inclusion and Islamic finance's ability to provide finance to lower- and middle-income individuals, which would help in building Nigeria's real economy. In addition, Islamic finance was seen as a way of getting the muchneeded foreign direct investment into the country to develop infrastructure.

According to an EFInA 2008 survey on financial inclusion in Nigeria, about 53\% of Nigeria's adults do not utilise financial services, thus explaining EFInA's enrolment and mobilisation into the network. EFInA brought together some stakeholders into a group, which included the Nigeria Deposit Insurance Corporation (NDIC), the National Insurance Commission (NAICOM), the Pension Commission (PENCOM), the Federal Inland Revenue, the Security and Exchange Commission (SEC), the Debt Management Office (DMO), the CBN and other market operators interested in offering Islamic financial products. These stakeholders aided in 
identifying and addressing regulatory and market issues to enhance the success of non-interest banking. The group recorded success, as various regulations were established (EFInA, 2009).

Our analysis showed that further progress was made when the CBN joined the IFSB [3] in January 2009 as a full member. In March the same year, the CBN banking supervision department issued a draft framework for the regulation and supervision of non-interest banking for comments from stakeholders (CBN, 2009). Islamic banking network recorded tremendous success in 2010. At the beginning of the year, the CBN set up a section for non-interest banking and issued a new banking model that allowed non-interest banks to operate at a national or regional level with capital bases of NGN10 billion for national banks and NGN5 billion for regional banks, under special licences. This finding is similar to those reported by Al Nasser and Mohammad (2013) and Laldin (2008) that the development of Islamic banking in Malaysia was strongly supported by the Malaysian government. Following CBN's changes on specialised banks, Jaiz International Bank raised the additional capital required through private individual and institutional investors and applied for a regional licence under the new name of Jaiz Bank Plc. The CBN granted Jaiz Bank Plc a regional licence to operate as a fully-fledged non-interest bank in December 2011 (CBN, 2011). Stanbic IBTC Bank Plc was given an approval to offer non-interest banking products at the same time (CBN, 2011).

We found that the Islamic banking network was becoming stronger in Nigeria-a religious and ethnically diverse country. However, the network was countered by several bodies (Callon, 1991), especially Christians and their associations, who questioned the decision of the CBN to allow Islamic banking. Some groups cited a religious divide because the CBN Governor was a Muslim. One criticism was that the CBN lacked the power to change the banking laws, as only the Nigerian National Assembly could do so (Kolalafe and Nnenna, 2011). Others even went to court to challenge the $\mathrm{CBN}$

One interviewee explained this as follows:

I can tell you there was lot of tension in the country. Several Christian and Christian associations questioned the decision of the CBN to change the banking model and allow Islamic banking. They saw it as a way of favouring Muslims.

Another interviewee elucidated:

In Nigeria, when anything Islamic or Christian is mentioned it sparked religious sentiment. The majority of Nigerian Muslims do not understand Christianity, and vice 
versa. Christians take anything Islamic as bad and Muslims think the same [about anything Christian] as well. Why would renowned Christians link Islamic banking to terrorism? Why the agitation? I don't know; I will tell you it is the religious tension that has been in Nigeria for several years.

This is similar to the findings reported by Mouawad (2009) and Wilson (2003), as in their studies Islamic banks were seen as a means of financing Islamic political movements that could destabilise the power of the ruling government and could also distort the existing economic system.

Our findings revealed that Despite all the criticisms the Islamic banking network kept becoming stronger and further interessement devices were stimulated for both Muslims and non-Muslims through publications in several newspapers, advertisements in the local media and posts on social media elaborating the advantages of Islamic banking and enrolling them into the network. For instance, one article informed Nigerians that Islamic banking is for anyone who does not want to pay any interest, not only Muslims - it is only called 'Islamic banking' because it is a non-interest banking system guided by Islamic legal principles and economics (Newswatch Nigeria, 2011). Other articles highlighted the acceptance of Islamic banking in other countries such as the United Kingdom (Yusuf, 2011; Gabriel, 2011; Jason, 2011). Jaiz Bank Plc began operation on 6 January 2012 through three branches: two located in the northern states of Kano and Kaduna and the third located in the Nigerian Federal Capital Territory, Abuja. Jaiz Bank Plc provides non-interest banking under Islamic principles, and it partners with the Islamic Bank of Bangladeshi Limited for technical and management support, based on the recommendations of the IDB, which is a shareholder of the bank (Jaiz, 2017). One interviewee explained as follows:

The bank is very good. Both Muslims and non-Muslims hold an account with them. The non-interest aspect attracts lots of people. Traditionally my friends and I pay a lot of interest when we take a loan due to the nature of our business, but with Jaiz this is different.

Jaiz Bank Plc raised more capital in subsequent years and later obtained a national licence, which enabled it to operate all over Nigeria. Islamic banking has become taken for granted practice in Nigeria, with several banks and other financial institutions offering Islamic financial instruments and the general public and the government participating in it (Latour, 1987; Callon, 1991). According to Jaiz Bank Plc's website, the bank is owned by over 26,000 shareholders, including both Muslims and non-Muslims, and the bank's balance sheet grew from NGN12 
billion in 2012 to around NGN62 billion in 2017, with financing assets of about NGN30 billion (Jaiz, 2017). Furthermore, our findings showed that, contrary to Haniffa and Hudaib (2010), Jaiz's banking products were designed to avoid riba (usury). According to one interviewee:

My business has prospered in the span of two years due to having non-interestgenerating transactions.

Another interviewee elucidated:

I recommend this bank to all Muslims. I believe their products avoid accruing interest, unlike conventional banks. You see, the owners of this bank are not seeking profit.

They are seeking to help Muslims in this country who do not want riba to avoid it.

However, our findings revealed that some Muslims still prefer to bank with conventional banks despite the fact that Jaiz has a branch within their proximity. Thus, conventional banks are still dominant in Nigeria.

An interviewee explained the reason for this preference as follows:

To me, banking depends on the economic circumstances. I am not rich, so I like to put my money where I can get something on top [interest] at the end of the month. I believe many people are like me. Otherwise, the majority of conventional banks in this state could have closed. I tell you, conventional banks have more customers than Jaiz. If Islamic banking is that good, we would have many new Islamic banks opening to compete with Jaiz.

\section{Conclusion}

The aim of this study was to investigate how Islamic banking developed in Nigeria, an ethnically and religiously diverse country. The paper uses ANT to analyse how the Islamic finance network was formed, the problems the network encountered and how the network became stable. The paper shows how the formation was messy and complex and involved various human and non-human actors, as well as the use of different interessement devices to interest different actors in the network that the focal actor (the Nigerian Muslim actor group) was building. The paper contributes to the literature on the evaluation of Islamic banking by providing a theoretical analysis of how Islamic finance has developed in Nigeria. The study contributes to the application of ANT in accounting and business research by drawing from both human and non-human actors.

The findings show that Islamic beliefs played a key role in the development of Islamic banking in Nigeria. A Nigerian Muslim group that represented both rich and poor individuals and 
desired banking that was in line with their faith saw the idea evolving throughout the country. This group of actors sold the idea to different Nigerians, as well as the government. Such financing became possible because of the liberalisation that took place in Nigeria in the 1980s, which resulted in the banking law changing in the 1990s, allowing for the establishment of non-interest banks.

Nigeria's unique socio-economic and political conditions have impacted Islamic banking's development. Despite the fact that Nigeria is a secular state, the government supported the development through the provision of an enabling environment and legal regulations. The Nigerian banking laws and the CBN Acts were both updated in order to support the development. These changes were done under the leadership of both Muslim and non-Muslim presidents and heads of the CBN, as the acceptance of such financing was seen by the various governments as a way of improving the country's real economy. The economy had recorded poor growth and development, leading to the different governments' adoption of various reforms. Politicians accepted that Islamic banking was an option that could cater for poor Nigerians' endemic problem of access to finance and could improve financial inclusion, so they pushed for its development.

The study's findings have practical implications for how governments in countries with diverse religions or ethnicities should take action when introducing new practices or concepts, such as Islamic finance, that align with one religion or ethnicity. The findings of this study suggest that publicising what the new practice or concept is in advance to the entire populace will enhance understanding and subsequent acceptance.

Finally, this paper suggests areas for future research on the development of Islamic finance in Nigeria specifically or sub-Saharan Africa in general to consider the following areas. First, future research could analyse why the development of Islamic finance has been slow in subSaharan African countries. Second, a comparative study could be conducted of different subSaharan Africa countries to investigate the factors aiding or hindering the development of Islamic finance. 


\section{Notes}

[1] The bank merged with Platinum Bank in 2005 and became Bank PHB (Platinum Habib Bank Plc). In 2011, the bank's licence was revoked by the CBN due to liquidity issues, and the bank's assets and some of its liabilities were transferred to Keystone Bank Limited.

[2] EFInA is a financial sector development initiative funded and supported by the UK Department for International Development (DFID) and the Bill and Melinda Gates Foundation to promote financial inclusion in Nigeria.

[3] The IFSB is an international organisation responsible for setting standards for the Islamic financial services industry. 


\section{References}

Al Nasser, S.A.S. and Muhammed, D.J. (2013), "Introduction to history of Islamic banking in Malaysia", Humanomics, Vol. 29 No. 2, pp. 80-87.

Beck, T., Cull, R. and Jerome, A. (2005), "Bank privatization and performance: Empirical evidence from Nigeria”, Journal of Banking \& Finance, Vol. 29 No. 8, pp. 2355-2379.

Benamraoui, A. (2008), "Islamic banking: The case of Algeria", International Journal of Islamic and Middle Eastern Finance and Management, Vol. 1 No. 2, pp. 113-131.

Callon, M. (1986) "Some elements of sociology of translation." In Law, J. (ed.). Power action and belief: a new sociology of knowledge. Routledge and Kegan Paul, London. Pp 196-233

Callon, M. (1987) "Society in the making: The study of technology as a tool for sociological analysis." In Pinch, T. J. (ed.). The Social Construction of Technological Systems: New Directions in the Sociology and History of Technology. Routledge: Cambridge, MA. Pp. 83104

Callon, M. (1991), "Techno-economic networks and irreversibility", in Law, J. (Ed.), A Sociology of Monsters: Essays on Power, Technology and Domination, Routledge, London. Pp. 132-161.

Central Bank of Nigeria (CBN) (2009), "Draft framework for the regulation and supervision of non-interest banks in Nigeria", available at:

www.cbn.gov.ng/out/circulars/bsd/2009/the\%20draft $\% 20$ framework $\% 20$ for $\% 20$ the $\% 20 \mathrm{regul}$ ation $\% 20$ and $\% 20$ supervision $\% 20 \mathrm{of} \% 20$ non-

interest\%20banks\%20(nibs)\%20in\%20nigeria.pdf (accessed 15 March 2016).

Central Bank of Nigeria (CBN) (2011), “Annual report: Chapter 2”, available at: https://www.cbn.gov.ng/Out/2012/publications/reports/rsd/arp-

2011/Chapter\%202\%20-\%20Monetary\%20Policy,\%20Surveillance\%20Activities\%20and\%2 0Operations\%20of\%20the\%20CBN\%20in\%202011.pdf (accessed 15 March 2016).

Central Bank of Nigeria (CBN) (2017), “About CBN” available at:

http://www.cbn.gov.ng/AboutCBN/history.asp (accessed 12 October 2017).

Central Intelligence Agency (CIA) (2017), "The World Fact Book, Africa, Nigeria". available at: https://www.cia.gov/library/publications/the-world-factbook/geos/ni.html (accessed 6 October 2017).

Cham, T. (2018), Determinants of Islamic banking growth: an empirical analysis. International Journal of Islamic and Middle Eastern Finance and Management, 11(1), pp.18-39.

Chua, W. F. (1995) Experts, networks and inscription in the fabrication of accounting images: a story of the representation of three public hospitals. Accounting Oganisations and Society, Vol 20 No 2/3, pp 111-145 
Collis, J. and Hussey, R. (2009), Business research: A practical guide for undergraduate and postgraduate students, Palgrave Macmillan, New York, NY.

Economist (2017) “Africa is Islamic banking's new frontier But the barriers to entry are high , available at: https://www.economist.com/news/finance-and-economics/21725037-barriersentry-are-high-africa-islamic-bankings-new-frontier (accessed 2 October 2017).

Enhancing Financial Innovation and Access (EFInA) (2017) "Non-interest finance working group" available at: http://www.efina.org.ng/our-work/capacity-building/financial-serviceproviders-and-regulators/non-interest-finance-working-group-nifwg/ (accessed 10 October 2016).

Enhancing Financial Innovation and Access (EFInA) (2008) "Access to Financial Service in Nigeria 2008 Survey" available at: http://www.efina.org.ng/our-work/research/access-tofinancial-services-in-nigeria-survey/(accessed 10 October 2016)

Eisenhardt, K. M. (1989), "Building theories from case study research", Academy of management review, Vol 14 No. 4, pp. 532-550.

Faye, I., Triki, T., and Kangoye, T. (2013) "The Islamic finance promises: evidence from Africa". Review of Development Finance, Vol. 3 No 3, pp. 136-151.

Gabriel, O. (2011), "Evolution and trends in Islamic banking”, Vanguard, 9 July, available at: https://www.vanguardngr.com/2011/07/evolution-and-trends-in-islamic-banking/ (accessed 25 March 2016).

Gelbard, E., Hussain, M., Maino, R., Mu, Y. and Yehoue, E.B. (2014), "Islamic finance in SubSaharan Africa: Status and prospects", IMF Working Paper WP/14/149. https://www.imf.org/external/pubs/ft/wp/2014/wp14149.pdf

Graf, W. D. (1988) The Nigerian state. London: James Currey.

Hair, J., Money, A., Samouel,P., Page, M. "Research Methods for Business", John Wiley and Sons Ltd., West Sussex, England.

Haniffa, R. and Hudaib, M. (2007), "Exploring the ethical identity of Islamic banks via communication in annual reports", Journal of Business Ethics, Vol. 76 No. 1, pp. 97-116, https://doi.org/10.1007/s10551-006-9272-5.

Haniffa, R. and Hudaib, M. (2010), "Islamic finance: From sacred intentions to secular goals", Journal of Islamic Accounting and Business Research, Vol. 1 No. 2, pp. 85-91.

Hassan, M. K. and Aliyu, S. (2018). A contemporary survey of Islamic banking literature. Journal of Financial Stability, 34 pp. 12-43.

Hussey, J. and Hussey, R. (1997) "Business research: a practical guide for undergraduate and postgraduates students" Macmillan Press Limited, Houndmills. 
Imam, P. and Kpodar, K. (2013), "Islamic banking: how has it expanded?" Emerging Markets Finance and Trade, Vol. 49 No. 6, pp. 112-137.

Islamic Financial Services Board (IFSB) (2016), "Islamic financial services industry stability report", available

http://www.ifsb.org/docs/IFSI\%20Stability\%20Report\%202016\%20(final).pdf (accessed 23 December 2017).

International Monetary Fund (IMF) (2017), "The IMF and Islamic Finance" available at: http://www.imf.org/external/themes/islamicfinance/ (accessed 14 September 2017).

Jaiz (2017), “About Jaiz", available at: http://jaizbankplc.com/about-jaiz/ (accessed 20 December 2017).

Jason, P. (2011), "Before we ignite another sectarian riot", Vanguard, 12 July, available at: www.vanguardngr.com/2011/07/before-we-ingite-another-sectarian-riot/ (accessed 25 September 2015).

Kaabachi, S. and Obeid, H. (2016), "Determinants of Islamic banking adoption in Tunisia: Empirical analysis", International Journal of Bank Marketing, Vol. 34 No. 7, pp. 1069-1091.

Khan, M.M. (2008), "Main features of the interest-free banking movement in Pakistan (19802006)", Managerial Finance, Vol. 34 No. 9, pp. 660-674.

Khan, M.M. and Bhatti, I. (2006), "Why interest-free banking and finance movement failed in Pakistan”, Humanomics, Vol. 22 No. 3, pp. 145-161.

Khan, M.S. and Mirakhor, A. (1990), "Islamic banking: Experiences in the Islamic Republic of Iran and in Pakistan", Economic Development and Cultural Change, Vol. 38 No. 2, pp. 353-375.

Kolalafe, B. and Nnenna, E. (2011), "CBN sets N10bn capital base for Islamic banks", Vanguard, 23 June, available at: www.vanguardngr.com/2011/06/cbn-sets-n10bn-capitalbase-for-islamic-banks/ (accessed 20 November 2016).

KPMG (2013), "Financial Services in Africa”, Cayman Islands, KPMG Africa Limited, KPMG International.

Lagarde, C. (2015), "Unlocking the promise of Islamic finance: speech by Christine Lagarde, Managing Director, International Monetary Fund at the Islamic Finance Conference, Kuwait City, Kuwait; November 11, 2015", available at: https://www.imf.org/en/News/Articles/2015/09/28/04/53/sp111115 (accessed 20 November 2016).

Laldin, M.A. (2008), "Islamic financial system: The Malaysian experience and the way forward", Humanomics, Vol. 24 No. 3, pp. 217-238. 
Latour, B. (1987) "Science in action: how to follow scientists and engineers through society", University Press, Milton Keynes.

Latour, B. (1992) "Where are the missing masses? sociology of a few mundane artifacts." In Bijker, W. E. and Law, J. (ed.). Shaping Technology-Building Society: Studies in Sociotechnical Change. MIT Press, Cambridge, MA, pp. 225-258

Law Nigeria (1991), available at: http://www.lawnigeria.com/LawsoftheFederation/Banksand-other-Financial-institutions-Act.html (accessed 6 October 2017).

Lewis, M.K. (2011), "Ethical principles in Islamic business and banking transactions", in Ariff, M. and Iqbal, M. (Eds.), The Foundations of Islamic Banking: Theory, Practice and Education, Edward Elgar, Northampton, MA. Pp. 39-50.

Maali, B. and Napier, C. (2010) "Accounting, religion and organisational culture: the creation of Jordan Islamic Bank", Journal of Islamic Accounting and Business Research, Vol. 1 No 2, pp.92-113,

Makkonen, H., Aarikka-Stenroos, L. and Olkkonen, R., (2012), "Narrative approach in business network process research-Implications for theory and methodology". Industrial Marketing Management, Vol. 41 No. 2, pp.287-299.

Mbawuni, J. and Nimako, S.G. (2017), "Determinants of Islamic banking adoption in Ghana", International Journal of Islamic and Middle Eastern Finance and Management, Vol. 10 No. 2, pp. 264-288, https://doi.org/10.1108/IMEFM-04-2016-0056.

Mohsin, M.I.A. (2005), "The practice of Islamic banking system in Sudan", Journal of Economic Cooperation, Vol. 26 No. 4, pp. 27-50.

Mouawad, S.G.A. (2009), "The development of Islamic finance: Egypt as a case study", Journal of Money Laundering Control, Vol. 12 No. 1, pp. 74-87.

Mustafa, D. A. and Idris, I. (2015), “The contributions of Islamic economics and institutions to modern Nigeria", Journal of Islam in Nigeria, Vol. 1 No. 1, pp. 36-58, available at:

http://www.iwf.com.ng/journal/vol_1_no_1/contributions_islamic_economics_institutions_m odern_nigeria.pdf (accessed 15 October 2017).

Naser, K., Jamal, A. and Al-Khatib, K. (1999), "Islamic banking: A study of customer satisfaction and preferences in Jordan", International Journal of Bank Marketing, Vol. 17 No. 3, pp. 135-151.

Newswatch Nigeria (2011), "Islamic banking: The CBN's role", 21 August, available at: https://articles.onlinenigeria.com/news/3194-islamic-banking\%3A-the-cbn\%E2\%80\%99srole.html (accessed 15 October 2017).

Okike, E.N.M. (1994), "Curious auditing regulation in Nigeria: A case study of cultural/political influences on auditing practice", The International Journal of Accounting, Vol. 29, pp. 78-91. 
Organisation of the Petroleum Exporting Countries (OPEC) (2017) "Members Countries, Nigeria" available at: http://www.opec.org/opec web/en/about us/167.htm (accessed 12 October 17).

Orisankoko, A.S. (2012), "The propagation of non-interest banking in Nigeria: An appraisal of the ideology risk", Journal of Islamic Banking and Finance, Vol. 29 No. 1, pp. 45-60.

Rammal, H.G. and Parker, L.D. (2013), "Islamic banking in Pakistan: A history of emergent accountability and regulation," Accounting History, Vol. 18 No. 1, pp. 5-29.

Ringim, K.J. (2014), "Perception of Nigerian Muslim account holders in conventional banks toward Islamic banking products", International Journal of Islamic and Middle Eastern Finance and Management, Vol. 7 No. 3, pp. 288-305, https://doi.org/10.1108/IMEFM-042013-0045.

Robson, K. and Bottausci, C.(2018), "The sociology of translation and accounting inscriptions: Reflections on Latour and Accounting Research", Critical Perspectives on Accounting, Vol. 54 , pp.60-75.

Rowan, D. (1952), "Banking in Nigeria: A study in colonial financial evolution", $P S L$ Quarterly Review, Vol. 5 No. 22, pp. 158-175.

Saaid, A.-E.E. (2005), "Allocative and technical inefficiency in Sudanese Islamic banks: An empirical investigation", in Iqbal, M. and Wilson, R. (Eds.), Islamic Perspectives on Wealth Creation, Edinburgh University Press, Edinburgh, pp. 142-154.

Saaid, A.-E.E., Rosly, S.A., Ibrahim, M.H. and Abdullah, N. (2003), “The X-efficiency of the Sudanese Islamic banks", IIUM Journal of Economics and Management, Vol. 11 No. 2, pp. 123-141.

Saini, Y., Bick, G. and Abdulla, L. (2011), "Consumer awareness and usage of Islamic banking products in South Africa", South African Journal of Economic and Management Sciences, Vol. 14, pp. 298-313.

Sarker, M.A.A. (1998), "Islamic banking in Bangladesh: Performance, problems and prospects", International Journal of Islamic Financial Services, Vol. 1 No. 3 pp. 15-36.

Soludo, C.C (2006), "Consolidating the Nigerian banking industry to meet the development challenges of the 21 st century", available at:

http://w1219.cbn.gov.ng/out/speeches/2004/govadd-6jul.pdf (accessed 22 November 2017).

Stanforth, C. (2006) "Using actor-network theory to analyse e-government implementation in developing countries", The Massachusetts Institute of Technology Information Technologies and International Development, Vol 3 No 3 pp. 35-60

Warde, I (2010) Islamic Finance in the Global Economy, Edinburgh, University Press, Edinburgh. 
Wilson, R. (2013), "The development of Islamic finance in the gulf cooperation council states", The Transformation of the Gulf: Politics, Economics and the Global Order, Vol. 146, pp. $47-76$.

World Atlas (2018) "Countries With The Largest Muslim Population In The World" available at: http://www.worldatlas.com/articles/countries-with-the-largest-muslim-populations.html (accessed 6 October 2017).

World Bank (2017) "The World Bank in Nigeria" available at:

http://www.worldbank.org/en/country/nigeria (accessed 6 October 2017).

Yanīkkaya, H. and Pabuçcu, Y. S. (2017), "Causes and solutions for the stagnation of Islamic Banking in Turkey”, ISRA International Journal of Islamic Finance, Vol. 9 No. 1, pp. 43-61.

Young, A. (1983), Saudi Arabia: The Making of a Financial Giant, New York University Press, New York, NY.

Yunusa, M. and Nordin, N.B. (2015), "Religious challenges of Islamic banking in Nigeria", International Journal of Academic Research in Business and Social Sciences, Vol. 5 No. 4, pp. 46-66.

Yusuf, A.U. (2011), "Who is afraid of an Islamic bank?" Daily Trust, 2 July, available at: https://www.dailytrust.com.ng/index.php/news-news/9177-us-donates-n56m-for-40-ruralprojects-in-nigeria (accessed 23 April 2016). 


\section{$\underline{\text { Interviews }}$}

\begin{tabular}{|c|c|c|}
\hline Date & Interviewee & Duration \\
\hline $19 / 10 / 15$ & Banker 1 & 1 hour 30 minutes \\
\hline $20 / 10 / 15$ & Accountant & 2 hours \\
\hline $20 / 10 / 15$ & Bank auditor & 1 hour \\
\hline $22 / 10 / 15$ & Lawyer & 1 hour 30 minutes \\
\hline $23 / 10 / 15$ & Banker 2 & 1 hour \\
\hline $11 / 01 / 16$ & Lawyer 1 & 1 hour 30 minutes \\
\hline $13 / 01 / 16$ & Matured student & 1 hour \\
\hline $14 / 01 / 16$ & Security & 1 hour \\
\hline $07 / 04 / 16$ & Imam & 1 hour \\
\hline 09/04/16 & Student & 1 hour \\
\hline $09 / 04 / 15$ & Civil servant & 45 minutes \\
\hline $20 / 05 / 16$ & Trader & 45 minutes \\
\hline $23 / 05 / 16$ & Trader & 45 minutes \\
\hline $25 / 05 / 16$ & Lawyer 2 & 1 hour \\
\hline $29 / 05 / 16$ & Hawker & 1.5 Hours \\
\hline $29 / 05 / 16$ & Civil servant & 1 hour \\
\hline $30 / 05 / 16$ & Business man 1 & 2 hours \\
\hline $30 / 05 / 16$ & Banker 3 & 1 hour \\
\hline $31 / 05 / 16$ & Banker 4 & 1hour 15 minutes \\
\hline $31 / 05 / 16$ & Teacher & 1 hour \\
\hline $20 / 08 / 18$ & Banker 1 & 1hour 15 minutes \\
\hline $20 / 08 / 18$ & Banker 2 & 1 hour 30 minutes \\
\hline $22 / 08 / 18$ & Lawyer 1 & 1 hour 15 minutes \\
\hline $23 / 08 / 18$ & Banker 5 & 2 hour \\
\hline $25 / 08 / 18$ & Business Man & 2 hours \\
\hline
\end{tabular}


20/08/18

$20 / 08 / 18$

$22 / 08 / 18$

$23 / 08 / 18$

25/08/18
Banker 1

Banker 2

Lawyer 1

Banker 4

Business Man 1hour 15 minutes

1 hour 30 minutes

1 hour 15 minutes

2 hour

2 hours 


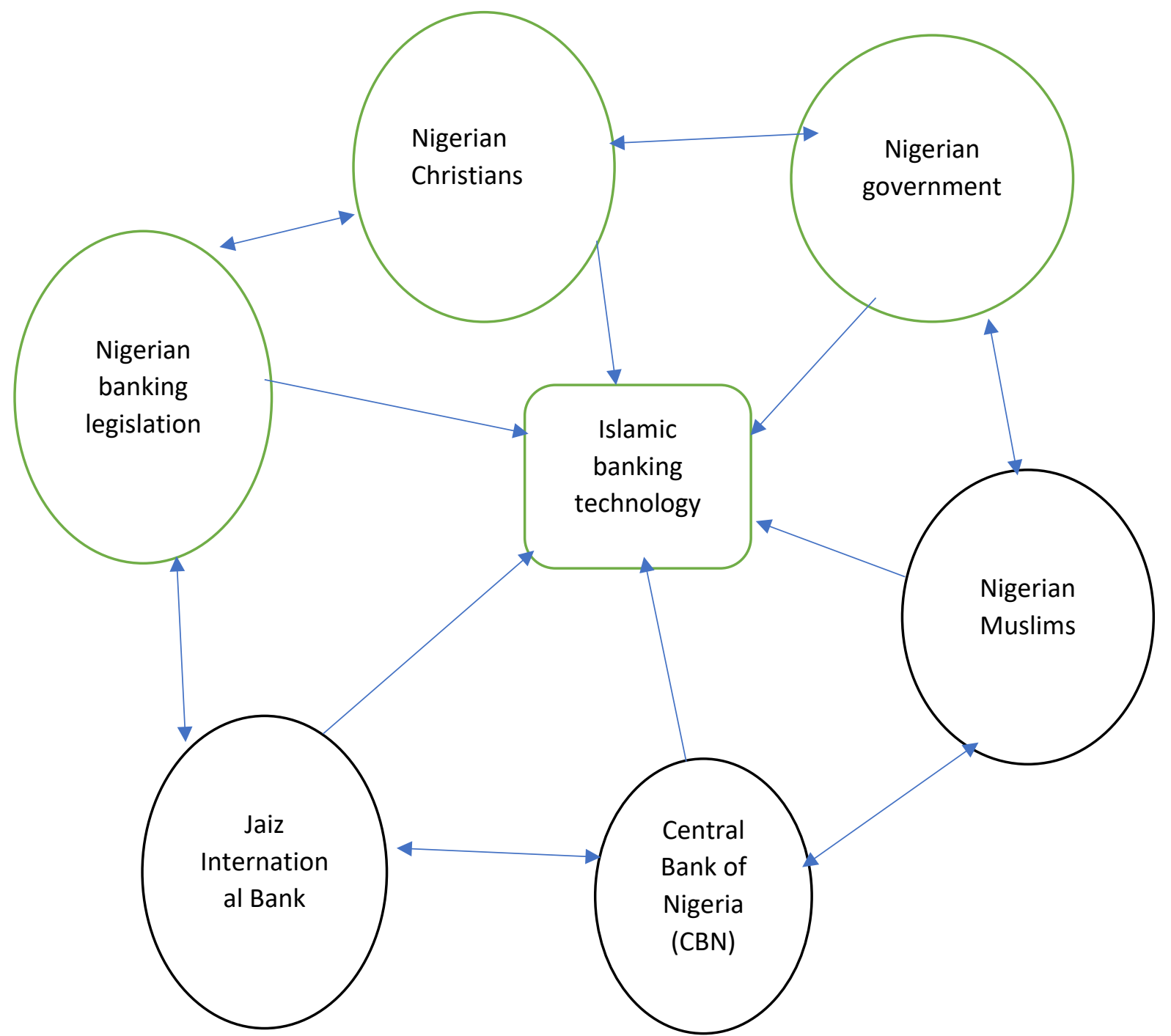

Figure 1: Actors considered in the development of Islamic banking 